\title{
UPAYA PENINGKATAN MUTU PERILAKU KESEHATAN REPRODUKSI ANAK JALANAN PEREMPUAN DI KOTA MALANG MELALUI PENDEKATAN TEORI KEPERAWATAN JOHNSON BEHAVIOR SISTEM MODEL (Efforts to Improve the Quality of Reproductive Health Behavior of Female Street Children with the Theoretical Approach Johnson Behavior Model Systems in Malang)
}

\author{
Nurul Aini \\ Fakultas Ilmu Kesehatan Universitas Muhamadiyah Malang \\ e-mail: nurulaini_56@yahoo.co.id
}

\begin{abstract}
Abstract: Adolescence is the age of the solid changes. At this time of great confusion adolescents experience in reaching his true identity. This period was characterized by growth, change, the emergence of a variety of occasions, and often face reproductive health risks. Sexual activity places adolescents at risk of challenges to various reproductive health problems. One part of the youth are a group of teenagers who are in a community of street children. The hard life on the streets with the unfavorable situation in which street children have to survive, forcing them to become adults before their time. Although they are socially categorized as a child, but almost all of them to adopt forms of behavior as a sign of rebellion against the maturity of some of the expectations that have been defined and determined by the local community. By adopting the mature form of behavior, they do not deserve the actions that should be done to children their age, which includes pre-marital sex (free sex), sexually transmitted diseases (STDs), use of drugs, homosexuality, and violence sexual. Easily they can acquire knowledge about sex influence attitudes toward sexual behavior of street children (Nurharjadmo, 1999). The low awareness and lack of knowledge of street children is likely to be one cause. Necessary handling and kepeduliaan of all parties to help alleviate them from such circumstances. Development of street children, especially in reproductive health issues for this still largely done by volunteers who are not health perpendidikan. Thus the involvement of the nursing profession as nursing care providers considered very important. This is consistent with the role of the nurse as educator, facilitator, coordinator, health reformers and observers (the National Workshop on Nursing 1983). This study aims to analyze the influence of coaching to nursing approach to the theory of "System Model Behavior" of the quality of reproductive health behavior of female street children. Research using experimental designs with predraft "Pre and Post Test Design. The population in this study were all female street children in Malang with a sample of respondents who take part in reproductive health coaching. Data is collected with the questionnaire enclosed. The results of the research done in getting the data that the quality of reproductive health behavior of female street children before treatment is given the majority (80\%) have good manners, the remainder (20\%), including less well with the average value of 17.76 . Whereas after given treatment to be better with an average increase in value to 20.68. The details are as many as $76 \%$ in both categories and $24 \%$ is very good. Wilcoxon match pair test results to explain the value Asymp.Sig test (2-tailed) or pvalue $<\alpha$, namely $(0.000<0.05)$, so it can be concluded that the act of coaching to
\end{abstract}


nursing approach to the theory of Johnson Behavior Model System can increase the mean average quality of reproductive health behavior of female street children in Malang.

\section{Keyword:}

Usia remaja merupakan usia yang padat perubahan. Pada masa ini remaja mengalami kebingungan besar dalam menggapai jati dirinya. Masa ini diwarnai oleh pertumbuhan, perubahan, munculnya berbagai kesempatan, dan seringkali menghadapi resiko-resiko kesehatan reproduksi. Kegiatan seksual menempatkan remaja pada tantangan resiko terhadap berbagai masalah kesehatan reproduksi. Setiap tahun diperkirakan di seluruh dunia terdapat 4 juta remaja melakukan aborsi, dan hampir 100 juta terinfeksi Penyakit Menular Seksual (PMS) yang dapat disembuhkan. Perkiraan terakhir adalah setiap hari ada 7.000 remaja terinfeksi HIV. Resiko kesehatan ini dipengaruhi oleh berbagai faktor yang saling berhubungan, misalnya tuntutan untuk kawin muda dan hubungan seksual, akses terhadap pendidikan dan pekerjaan, ketidaksetaraan jender, kekerasan seksual dan pengaruh media massa maupun gaya hidup yang popular (Jurnal OutLook, 2008). Salah satu bagian dari remaja adalah kelompok remaja yang berada dalam komunitas anak jalanan. Mereka memiliki karakteristik sosial yang berbeda antara satu dengan lainnya, tergantung usia, jenis kelamin, pendidikan, hubungan dengan orang tua, aktivitas, lingkungan dan penghasilan (Depsos RI, 1999). Kehidupan yang keras dijalanan dengan situasi yang kurang kondusif dimana anak jalanan harus bertahan hidup, memaksa mereka menjadi dewasa sebelum waktunya. Meskipun secara sosial mereka dikategorikan sebagai anak, namun hampir semuanya mengadopsi bentuk-bentuk perilaku kedewasaan sebagai tanda pemberontakan terhadap beberapa harapan yang telah ditetapkan serta ditentukan oleh masyarakat sekitar. Dengan mengadopsi bentuk perilaku kedewasaan, mereka melakukan tindakan yang seharusnya belum pantas dilakukan pada anak-anak seusia mereka, yang meliputi hubungan seksual pra nikah (free sex), terkena penyakit menular seksual (PMS), pemakaian obat-obat terlarang, homoseksual, dan kekerasan seksual. Di antara anak jalanan ada yang melakukan hubungan seksual dengan sesama anak jalanan, menjadi Pekerja Seks Komersial (PSK), atau menjadi korban sodomi anak jalanan lain yang lebih besar atau lebih berkuasa. Keadaan demikian dapat mengkondisikan pengertian anak-anak jalanan yang lain bahwa perilaku tersebut bebas dilakukan dan tidak perlu ada aturanaturan tertentu. Apalagi tindakan-tindakan tersebut tidak ada sanksi atau hukuman baik dari lingkungan mereka sendiri maupun dari 
luar lingkungannya. Sesuatu perbuatan yang dilakukan tanpa mendapat sanksi dapat ditafsirkan bahwa sesuatu tersebut benar atau baik atau bahkan dianggap boleh dilakukan bagi sebagian orang. (Anonymus. 2003. ) Pendidikan seksual dan resiko kesehatan reproduksi sudah saatnya diberikan kepada kalangan remaja tersebut. Sebab selama ini anak jalanan memperoleh pengetahuan seksnya dari teman sebaya, atau anak jalanan yang lebih tua, baik dari membaca buku porno, atau pun menonton film/ VCD porno. Mudahnya mereka memperoleh pengetahuan mengenai seks mempengaruhi sikap anak jalanan terhadap perilaku seksual (Nurharjadmo, 1999).

Hasil penelitian (Tjahyorini, 2004) menunjukkan permasalahan anak jalanan dominan disebabkan oleh kemiskinan atau ketidakmampuan keluarga (98 \%), disamping juga disebabkan adanya ketidakserasian keluarga (33 \%) dan kekerasan dalam keluarga (23 Kehadiran anak jalanan tidak bisa dilepaskan dari keberadaan Kota besar. Semakin cepat perkembangan sebuah kota semakin besar jumlah anak jalanan. Di kota Malang hingga kini telah tercatat jumlah anak jalanan dengan angka mencapai kisaran 600 orang, dengan proporsi sebagian besar adalah usia remaja. Mereka tersebar di seluruh wilayah Kota Malang. Sebagian diantara mereka ada yang berada dibawah naungan lembaga-lembaga perlindungan anak jalanan, rumah singgah, maupun hidup bebas di jalanan tanpa terikat dengan lembaga manapun. Masalah kesehatan reproduksi menjadi masalah yang paling menonjol saat ini. Sebuah kegiatan Bakti Sosial berupa pemeriksaan kesehatan yang diadakan oleh Jaringan Kemanusiaan Jawa Timur pada awal tahun 2010 telah menjadi bukti yang tak terbantahkan. Dari 150 anak jalanan yang mengikuti tes kesehatan seluruhnya terdeteksi menderita infeksi PMS , 12 orang diantaranya terindikasi HIV positif. Rendahnya kesadaran serta kurangnya pengetahuan anak jalanan kemungkinan menjadi salah satu penyebabnya. Selain itu lemahnya motivasi telah menyebabkan sikap anak jalanan terhadap resiko reproduksi yang negatif . Hasil wawancara dengan mereka, menunjukkan bahwa rata-rata anak jalanan pasrah begitu saja dengan kondisinya. Mereka menyatakan bahwa keadaan sebagai anak jalanan menyebabkan mereka merasa wajar tentang penyakit yang dideritanya. Hal tersebut sangat memprihatinkan. Perlu penanganan dan kepeduliaan dari semua pihak untuk membantu mengentaskan mereka dari keadaan yang demikian. (sumber informasi diungkapkan oleh Tedja Bawana selaku ketua Lembaga Perlindungan Anak Kota Malang). Dorothy E. Johnson melalui teorinya "Behavior Sistem Model "meyakini bahwa asuhan keperawatan dilakukan untuk membantu individu memfasilitasi tingkah laku yang efektif dan efisien untuk mencegah 
timbulnya penyakit. Pembinaan terhadap anak jalanan khususnya dalam masalah kesehatan reproduksi selama ini sebagian besar masih dilakukan oleh tenaga relawan yang bukan perpendidikan kesehatan. Sehingga keterlibatan profesi perawat sebagai pemberi asuhan keperawatan dinilai sangat penting. Hal ini sesuai dengan peran perawat sebagai edukator, fasilitator, koordinator, pembaharu serta pengamat kesehatan (Lokakarya Nasional Keperawatan 1983). Perawat dapat melakukan berbagai tindakan keperawatan guna membantu mengubah perilaku serta menggugah kesadaran mereka khususnya terhadap resiko kesehatan reproduksi remaja. Maka dari itu peneliti tertarik untuk melakukan penelitian dengan judul upaya peningkatan mutu perilaku kesehatan reproduksi anak jalanan perempuan melalui pendekatan teori keperawatan Johnson Behavior Sistem Model di Kota Malang

Tujuan dari penelitian ini adalah untuk mengetahui pengaruh pemberian pembinaan dengan pendekatan teori keperawatan "Behavior System Model" terhadap mutu perilaku kesehatan reproduksi remaja jalanan perempuan

\section{BAHAN dan METODE}

Penelitian ini merupakan penelitian pra eksperimental dengan rancangan "Pre dan Post Test Design.
Subyek penelitian ini sebanyak 25 orang yang mengikuti kegiatan pembinaan kesehatan reproduksi di kota Malang.

Variabel independen dalam penelitian ini adalah pembinaan dengan pendekatan teori keperawatan "Behavior sistem model", sedangkan variabel dependen adalah mutu perilaku kesehatan reproduksi remaja jalanan perempuan.

Instrumen yang digunakan dalam pengumpulan data adalah quesioner informasi perilaku kesehatan reproduksi. Quesioner diberikan 2 kali sebelum dan sesudah pembinaan dilakukan. Responden diberikan quesioner tentang perilaku kesehatan reproduksi. Hasil wawancara yang dilakukan sebelum pemberian perlakuan $\left(\mathrm{O}_{1}\right)$ disebut pre-test, dan hasil wawancara sesudah pembinaan $\left(\mathrm{O}_{2}\right)$ disebut post-test. Penelitian dilakukan pada pada saat yang berurutan, awal pertemuan (pre test), kemudian diberikan pembinaan dan berikutnya akhir pertemuan (post test). Untuk mengevaluasi perilaku digunakan Modul kesehatan reproduksi yang sudah disosialisasikan oleh BKKBN.

Analisis data menggunakan statistik analitik non parametrik uji komparasi antara 2 kelompok sampel dependen yaitu : Wilcoxon match pair test. 


\section{HASIL PENELITIAN}

Dari hasil penelitian yang di lakukan peneliti di dapatkan data bahwa mutu perilaku kesehatan reproduksi anak jalanan perempuan sebelum diberikan perlakuan tergolong baik. Hal ini terbukti bahwa sebagian besar (80\%) memiliki perilaku yang baik, sisanya (20\%) termasuk kurang baik dengan nilai rata-rata 17,76 . Sedangkan mutu perilaku kesehatan reproduksi anak jalanan perempuan setelah diberikan perlakuan menjadi lebih baik dengan peningkatan nilai rata-rata menjadi
20,68. Dengan rincian sebanyak 19 orang (76\%) dalam kategori baik dan 6 orang (24\%) kategori sangat baik. Dari total responden ( 25 orang), terdapat 17 responden mengalami perubahan hasil antara pre-test dan post-test dengan kenaikan nilai (skor) bervariasi. Sedangkan sisanya (8 responden) tidak mengalami perubahan nilai (skor) meskipun kategori perilaku mereka tergolong baik. Jika digambarkan dalam bentuk kurva, maka akan tampak adanya pergeseran kurva seperti terlihat dibawah ini:

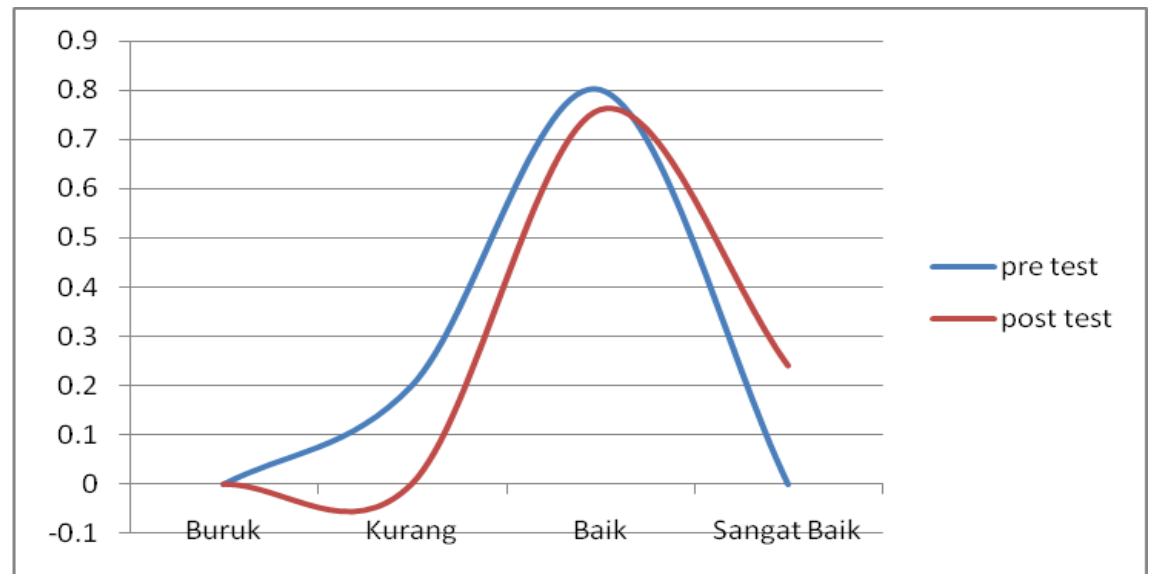

Gambar : Kurva Perbedaan Mutu Perilaku Kesehatan Reproduksi Jalanan Perempuan di Kota sebelum dan Sesudah diberikan Perlakuan

Dengan menggunakan bantuan tabel contingency Wilcoxon, didapatkan hasil uji Wilcoxon match pair test sebagai berikut :

Descriptive Statistics

\begin{tabular}{|l|r|l|r|r|r|}
\hline & $\mathrm{N}$ & Mean & Std. Dev iation & \multicolumn{1}{c|}{ Minimum } & Maximum \\
\hline Pretest & 25 & 17.7600 & 2.91947 & 11.00 & 22.00 \\
Postest & 25 & 20.6800 & 2.51197 & 17.00 & 26.00 \\
\hline
\end{tabular}

Pada tabel Descriptive Statistics memiliki nilai 17,76 sedangkan setelah output SPSS, dapat dijelaskan bahwa dari 25 orang anak jalanan perempuan yang diamati sebelum diberikan perlakuan rata-rata diberikan perlakuan rata-rata nilai sikap meningkat menjadi 20,68. Berdasarkan hasil descriptive statistics tersebut dapat 
dikatakan bahwa tindakan pembinaan meningkatkan nilai rata-rata mutu perilaku melalui pendekatan teori keperawatan kesehatan reproduksi anak jalanan Johnson Behavior Sistem Model dapat perempuan di Kota Malang

\section{Wilcoxon Signed Ranks Test}

\begin{tabular}{|c|c|c|c|c|}
\hline \multicolumn{5}{|c|}{ Ranks } \\
\hline & & $\mathrm{N}$ & Mean Rank & Sum of Ranks \\
\hline Postest - Pretest & $\begin{array}{l}\text { Negative Ranks } \\
\text { Positive Ranks } \\
\text { Ties } \\
\text { Total }\end{array}$ & $\begin{array}{c}O^{\mathrm{a}} \\
17^{\mathrm{b}} \\
8^{\mathrm{c}} \\
25\end{array}$ & $\begin{array}{r}.00 \\
9.00\end{array}$ & $\begin{array}{r}.00 \\
153.00\end{array}$ \\
\hline
\end{tabular}

a. Postest $<$ Pretest
b. Postest $>$ Pretest
c. Postest $=$ Pretest

Pada tabel peringkat (Ranks) output SPSS, dapat dijelaskan bahwa dari 25 orang responden, tidak terdapat responden yang memiliki nilai mutu perilaku kesehatan reproduksi sesudah diberikan perlakuan dengan nilai menjadi lebih jelek (berkurang) dibandingkan sebelumnya. Terdapat 17 responden memiliki nilai yang meningkat sesudah diberikan perlakuan, dan sisanya sebanyak 8 responden memiliki nilai yang sama baik sebelum maupun sesudah perlakuan.

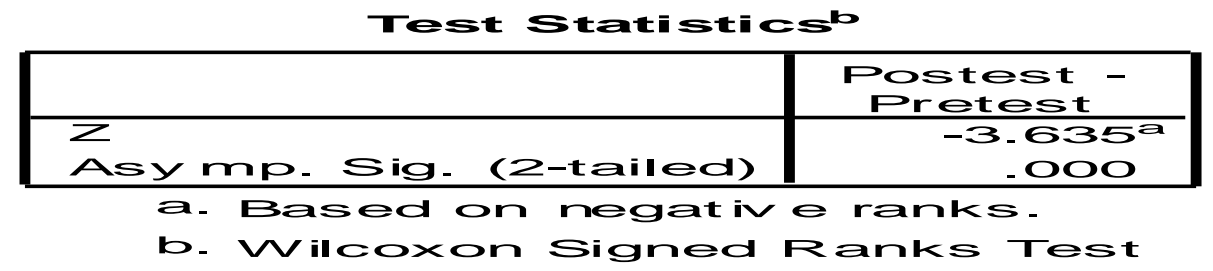

Dari pengujian tersebut, didapatkan nilai Asymp.Sig (2-tailed) atau $p$-value $<\alpha$ yaitu $(0,000<0,05)$, sehingga keputusan yang diambil adalah tolak $\mathrm{H}_{0}$ yang berarti

\section{PEMBAHASAN}

Adanya peningkatan mutu perilaku kesehatan reproduksi responden sebelum dan sesudah diberikan pembinaan disebabkan oleh pengetahuan mereka yang bertambah selama mengikuti kegiatan pelatihan pembinaan. Informasi yang bahwa ada peningkatan mutu perilaku kesehatan reproduksi anak jalanan perempuan di Kota Malang sebelum dan sesudah dilakukan penelitian.

dikemas dalam bentuk pelatihan dapat diikuti dengan baik oleh responden. Hal ini dapat disebabkan karena jenis materi yang baru dan menarik serta sesuai dengan kebutuhan mereka saat ini. Penyajian materi dengan metode pembelajaran yang bervariasi membuat mereka merasa nyaman 
dan tetap bersemangat dalam mengikuti kegiatan dari awal sampai selesai. Faktor lain yang mendukung adalah usia responden tergolong remaja serta tingkat pendidikan yang sebagian besar dalam taraf menempuh pendidikan tingkat menengah sangat memungkinkan menjadikan mereka mudah menerima informasi yang diberikan.

Hasil penelitian ini juga tergambar dalam kurva yang bergeser ke kanan (seperti pada gambar 6.3), yang berarti bahwa perlakuan berupa pembinaan dengan pendekatan teori keperawatan "Behavior System Model" memberikan dampak perubahan positif. Hal ini membuktikan bahwa materi dan strategi yang diberikan pada saat pembinaan sesuai dengan sasaran. Meskipun menunjukkan peningkatan nilai perilaku pada akhir penelitian, namun masih terdapat 8 responden yang memiliki nilai yang sama antara pretest dan posttest (seperti yang tertera dalam tabel 6.1 dan tabel wilcoxon sign rank test). Hal tersebut sangat wajar terjadi, salah satunya seperti disebutkan diatas, bahwa peneliti tidak mengendalikan secara khusus terhadap faktor budaya, adat dan pengalaman. Anak jalanan yang terbiasa hidup bebas, tidak selalu dapat berfikir panjang dengan penuh konsentrasi. Saat kegiatan pembinaan berlangsung, melalui wawancara mendalam didapatkan data bahwa mereka membutuhkan pelajaran tentang ilmu kesehatan, tetapi mereka tidak bisa terlalu lama dalam posisi dan keadaan yang formal. Meskipun kegiatan penelitian telah disesuaikan dengan situasi dan karakter mereka, ternyata masih menjadi keluhan dan hambatan bagi anak jalanan. Sehingga dalam menjawab pertanyaan dalam kuesioner, beberapa responden kurang dapat berkonsentrasi dengan baik.

$$
\text { Menurut Notoatmodjo (2003), }
$$
pendidikan dan pelatihan merupakan upaya untuk mengembangkan sumber daya manusia, terutama untuk mengembangkan kemampuan intelektual dan kepribadian manusia. Sedangkan pelatihan merupakan bagian dari proses pendidikan, dengan tujuan untuk meningkatkan kemampuan atau keterampilan khusus seseorang atau sekelompok orang. Dalam penelitian ini, kegiatan pembinaan dimaksudkan untuk membantu merubah perilaku kesehatan reproduksi anak jalanan perempuan dengan harapan jika perilakunya baik, maka responden memiliki kemampuan untuk menghindari perilaku kesehatan reproduksi yang berisiko. Hasil penelitian Wijayanti RR (2005) tentang perubahan pengetahuan dan sikap tentang kesehatan reproduksi anak jalanan di Jawa Tengah membuktikan bahwa anak jalanan yang mendapatkan pendampingan dalam proses belajar kesehatan reproduksi memiliki pengetahuan dan sikap lebih baik dibandingkan dengan yang tidak mendapatkan pendampingan. Begitu pula dengan penelitian oleh Hasanah 
Lina (2004) yang membuktikan bahwa terdapat perbedaan signifikan antara pengetahuan dan sikap remaja (santri di pondok pesantren) yang telah mendapatkan program Kesehatan Reproduksi Remaja (KRR) dengan yang belum pernah mendapatkan. Dengan demikian penelitian ini juga sekaligus mendukung kebenaran teori keperawatan Model Sistem Tingkah Laku yang dikemukakan oleh Dorothy E. Johnson bahwa manusia sebagai system tingkah laku yang terdiri dari beberapa subsistem (the echievment, attachment, aggressive protective, dependency, ingestive, eliminative, dan sexual ) saling berhubungan satu sama lain, berfungsi membantu system perilaku, dimana pemberian pengetahuan dan motivasi pada individu dapat memberi pengaruh pada kecenderungan individu dalam menentukan pilihan-pilihan dan menghasilkan suatu perbuatan. Johnson juga menegaskan bahwa keperawatan adalah sebuah pengatur eksternal yang memiliki peran untuk mengembalikan keseimbangan dan kestabilan dengan menghambat, merangsang atau memperkuat perilaku-perilaku tertentu (control mechanism). Dalam hal ini Johnson lebih menekankan pentingnya pendekatan melalui health promotion bagi kinerja seorang perawat dalam upaya merubah sikap dan perilaku klien.

\section{SIMPULAN dan SARAN}

\section{Simpulan}

Ada peningkatan mutu perilaku kesehatan reproduksi anak jalanan perempuan setelah diberikan tindakan keperawatan dengan menggunakan pendekatan teori Johnson Behavior Sistem Model di Kota Malang

\section{Saran}

Bagi Imu Keperawatan, diharapkan menjadi bahan evaluasi dalam menentukan sasaran pemberian pendidikan kesehatan tentang kesehatan reproduksi dengan melibatkan anak jalanan sebagai prioritas penting khususnya pada program keperawatan maternitas. Bagi masyarakat, masyarakat tidak perlu apriori terhadap keberadaan anak jalanan, mengingat mereka pun sama dengan anak remaja pada umumnya, masyarakat hendaknya bersikap baik dan membantu menciptakan lingkungan belajar yang kondusif bagi anak jalanan. Bagi pemerintah, pemerintah daerah hendaknya berusaha melakukan kerjasama lintas sektoral guna mengatasi masalah kesehatan khususnya pada kelompok anak jalanan. Bagi peneliti selanjutnya, diharapkan bagi peneliti selanjutnya untuk menyempurnakan dengan melakukan penelitian sejenis dengan menggunakan instrumen dan waktu yang lebih memadai. 


\section{DAFTAR RUJUKAN}

Alligood, Tomey. 2006. Nursing Theorist and Their Work. Sixth edition. Publish by Mosby Elsever, Westline industrial Drive St. Louis Missouri.

Anonymus, 2001, Children on Jakarta Street is Childhope Research no 3. Manila : UNICEF.

Anonymus, 2003. Dialog Interaktif Kesehatan Reproduksi Remaja “ Jangan Terjebak Kegiatan Pra Nikah" Ceria. Diakses dari http:// www.bkkbn.go.id/ article detail.php?aid $=327$ pada tanggal 20 Maret 2010

Anonymus, 2004. Pergeseran Norma Perilaku Sexual Kaum Remaja. Sebuah penelitian terhadap remaja Jakarta : PT. Grafindo Persada

Azwar, S. 2003. Sikap Manusia ; Teori dan Pengukurannya. Yogyakarta : Pustaka Pelajar

Daili, Makes, Zubier, dkk. 2005. Infeksi Menular Seksual, EDisi ketiga Jakarta : Balai Penerbit FKUI

Dariyo, Agoes. 2004. Psikologi Perkembangan Remaja. Ghalia Indonesia : Bogor

Depsos RI, 1999. Kategori Penerima Pelayanan oleh Dinas Sosial. Jakarta

Depkes RI. Dirjen Pembinaan Kesehatan Masyarakat, 1994. Kumpulan materi Kesehatan Reproduksi Remaja. Jakarta

Dinsos Propinsi Jatim. 2001. Penanganan Anak Jalanan.

Djoko, S. 2003. Proses Belajar Aktif Kesehatan Reproduksi Remaja. Jakarta : kerjasama BKKBN dan Word Bank

Djuanda, Hamzah, Aisah, dkk. 2007. Ilmu Penyakit Kulit dan Kelamin ed. Kelima, Jakarta : Balai Penerbit FKUI.

Ewles, Linda, Ina Simnett, 1992. Promoting Health, A Practical Guide Second edition. Scutari Press, a division of Scutari Project Ltd. Viking House, Harrow.
Gufron, Ali. 2000. Pengajaran Yang Efektif : Pedoman bagi Pembina Kesehatan , Penerbit EGC. Jakarta

Glasier, Anna, Gebbie, Ailsah. 2000. Family Planning and Reproductive Healthcare. Published by arrangement with Churchill livingstone, a division of Elsevier Science.

Hamid, Achir Yani. 1999. Asuhan Keperawatan Kesehatan Jiwa pada Anak dan Remaja, Widya Medika. Jakarta

Irwanto, Mohammad Farid, dan Jeffry Anwar. 1998. Ringkasan Analisa Situasi Anak yang Membutuhkan Perlindungan Khusus. PKPM Atma Jaya. Departemen Sosial, UNICEF. Jakarta.

Kartono, Kartini. 1985. Bimbingan bagi Anak dan Remaja yang Bermasalah. Jakarta : CV Rajawali

Munajat, Nanang. 1999. Modul Pelatihan Risiko Reproduksi Remaja, PKBI. Jakarta

Notoatmodjo, S. 2003. Ilmu Kesehatan Masyarakat. Jakarta. Rineksa cipta

Nurharjadmo, W. 1999. Seksualitas Anak Jalanan, Yogyakarta : Ford Foundation dengan Pusat Peneltian Kependudukan universitas Gadja Mada Yogyakarta.

Nursalam, 2001. Metodologi Riset Keperawatan, Jakarta. CV Agung Seto

Nursalam, 2003. Konsep dan Penerapan metodologi Penelitian Ilmu Keperawatan Salemba Medika

Pemerintah Kota Malang. 2005. Pemetaan dan Pemberdayaan Anak. Malang

Pearce, Evelyn C. 2000. Anatomi dan Fisiologi untuk Paramedis. PT Gramedia : Jakarta

Pusat Studi Wanita, 1998. Situasi Anak Jalanan Perempuan di Semarang. Semarang. Diakses dari http://www.tempo.co.id/medika/arsi p/012003/pus_1.htm pada tanggal 20 Januari 2010

Sedyaningsih, Endang, 2001. Prevalensi Infeksi Menular Seksual dan 
Perilaku Berisiko Terkait di Kalangan Anak Jalanan di Jakarta. Majalah Gemari. diakses diakses dari

http://www.bkkbn.go.id/article_deti 1.php?aids $=327$ pada tanggal 2 Februari 2010.

Sinar Grafika, redaksi. 2003. Undangundang Perlindungan Anak (UU RI No. 23 tahun 2002). Jakarta : Sinar Grafika

Soetjingsih, 1998. Tumbuh Kembang Anak. Jakarta : Penerbit EGC

Soetjingsih, 2004. Tumbuh Kembang Remaja dan Permasalahannya. Jakarta : CV. Agung Seto

Stuart, Sundeen. 1998. Buku saku Keperawatan Jiwa. Jakarta .EGC.

Sub Dinas Kesehatan Keluarga dan Gizi Propinsi Jatim, 2001. Pedoman Reproduksi Sehat bagi Remaja di Sekolahan. Jatim

Sudjana. 1996. Metode Statistika. Bandung. Torsito

Sugiyono. 2006. Metode Penelitian Bisnis. Bandung : CV Alfabeta

Suliha, U. 2002. Pendidikan Kesehatan dalam Keperawatan. Jakarta. EGC.

Supartini, Yupi. 2002. Konsep Dasar Keperawatan Anak. Jakarta . Penerbit EGC.

Suratini, dkk. 2005. Gambaran Pengetahuan Siswa Kelas I SMU Pasundan Tanjungsari Kab. Sumedang Mengenai Kesehatan Reproduksi. Jurnal Kebidanan dan Keperawatan Aisyiyah. STIKES Aisyiyah Yogyakarta.

Tjahjorini, Sri. 2001. Persepsi Anak Jalanan terhadap Bimbingan Sosial melalui Rumah Singgah di Kotamadya Bandung. Institur Pertanian Bogor. Bogor.

Usumantri, Jujur, S. 2001. Filsafat Ilmu Sebuah Pengantar Populer. Jakarta : Pustaka Sinar harapan

W.F. Maramis. 1994. Ilmu Kedokteran Jiwa - Surabaya Airlangga university Press. Jakarta : Balai Penerbit
Fakultas Kedokteran Universitas Indonesia

Wijayanti RR, 2005. Perubahan Pengetahuan dan Sikap tentang Kesehatan Reproduksi Anak Jalanan di Jawa Tengah. Tesis. Universitas Muhammadiyah Surakarta.

Yayasan Duta Awam, 1997. Situasi Anak Jalanan Perempuan di Semarang. Semarang diakses dari http://www.tempo.co.id/medika/arsip /012003/pus-1.htm pada tanggal 11 Januari 2010.

Yayasan Setara, 1999. Situasi Anak Jalanan Perempuan di Semarang. Semarang diakses dari http://www.tempo.co.id/medika/arsip /012003/pus-1.htm pada tanggal 11 Januari 2010

Yusuf, Syamsul. 2005. Psikologi Perkembangan Anak dan Remaja. PT Remaja Rosdakarya : Bandung. 